\title{
Pengaruh Kualitas Pelayanan Terhadap Minat Beli Konsumen Pada Nasi Kuning Puput Di Kayumalue
}

\author{
Ermawati Ermawati ${ }^{*}$, Riza Putri Utami², Irham Pakkawaru ${ }^{3}$ \\ ${ }^{1}$ Ekonomi Syariah, Fakultas Ekonomi dan Bisnis Islam, IAIN Palu \\ 2 Ekonomi Syariah, Fakultas Ekonomi dan Bisnis Islam, IAIN Palu \\ ${ }^{3}$ Ekonomi Syariah, Fakultas Ekonomi dan Bisnis Islam, IAIN Palu
}

ABSTRAK

Tujuan penelitian ini untuk mengetahui apakah kualitas pelayanan Nasi Kuning Puput di Kayumalue berpengaruh terhadap minat beli konsumen dan bagaimanakah kualitas pelayanan Nasi Kuning Puput di Kayumalue mempengaruhi minat beli konsumen dalam Perspektif Ekonomi Islam. Jenis penelitian ini adalah penelitian survei dengan pendekatan kuantitatif, dimana populasi dalam penelitian ini adalah seluruh konsumen Nasi Kuning Puput. Adapun sampelnya berjumlah 40 orang berdasarkan rumus Hair. Teknik pengambilan sampel dalam penelitian ini adalah Nonprobability Sampling dengan cara accidental sampling. Hasil Penelitian ini menunjukkan bahwa kualitas pelayanan berpengaruh besar terhadap minat beli konsumen pada Nasi Kuning Puput di Kayumalue. Dimana besaran pengaruhnya dapat dilihat pada tabel Cofficients pada kolom Standardized Coefficient yaitu sebesar 0,543 atau 54,3\%, sedangkan sisanya dijelaskan oleh variable independen lain yang tidak termasuk dalam penelitian ini. Dalam Perspektif Ekonomi Islam Nasi Kuning Puput telah terwujud hubungan antara manusia karena pelaku usaha Nasi Kuning Puput tidak membedakan-bedakan antara konsumen yang satu dengan konsumen yang lainnya, semua dilayani dengan ramah, cepat dan tanggap.
INFORMASI

ARTIKEL

Katakunci:

Fintech, pengetahuan, kemudahan, resiko, transaksi, minat 


\section{Pendahuluan}

Salah satu kebutuhan pokok yang menjadi kebutuhan utama manusia adalah kebutuhan akan makanan dan minuman. Banyak cara yang diperoleh oleh manusia untuk mendapatkan makanan tersebut yaitu dengan mengolahnya sendiri maupun dengan cara yang instan atau dengan cara membeli makanan pelaku usaha kuliner.

Seiring dengan kesibukan masing-masing orang seringkali mengolah makanan sendiri menjadi sesuatu yang membutuhkan waktu untuk mengolahnya sehingga tidak jarang orang cenderung untuk mencari alternatif lain untuk memenuhi kebutuhan makannya yaitu dengan cara membeli makanan jadi. Salah satu makanan jadi yang sering diburu oleh sebagian masyarakat untuk dikonsumsi sebagai sarapan pagi adalah nasi kuning.

Banyaknya permintaan terhadap makanan jadi yang dalam hal ini adalah nasi kuning, telah mendorong munculnya banyak pelaku usaha yang menjual makanan tersebut. Hal ini tentu saja mendorong timbulnya persaingan di antara pelaku usaha nasi kuning.

Untuk menghadapi persaingan yang semakin meningkat, masingmasing pelaku usaha nasi kuning dari kalangan pedagang kaki lima tersebut, dituntut untuk membuat, menyusun, dan menetapkan strategi-strategi yang tepat dengan tujuan untuk memenangkan persaingan, meraih laba, dan melanjutkan kegiatan usaha atau bisnis tersebut. Hal ini membuat pelaku usaha untuk berlomba-lomba merebut dan mempertahankan pangsa pasarnya. Salah satu strategi memenangkan persaingan adalah dengan memberikan kualitas pelayanan maksimal yang dapat memuaskan konsumen.

Kualitas pelayanan menjadi salah satu faktor yang mempengaruhi kepuasan konsumen. Kualitas pelayanan merupakan suatu strategi untuk menarik lebih banyak konsumen baru, mempertahankan konsumen yang ada, menghindari berpindahnya konsumen dan menciptakan keunggulan khusus. Setiap pelaku usaha yang mengutamakan kualitas pelayanan yang baik akan berdampak pada kepuasan pelanggan. Kualitas pelayanan sebagai usaha untuk mewujudkan kenyamanan terhadap konsumen agar konsumen merasa mempunyai nilai yang lebih dari yang diharapkan. Harapan konsumen merupakan faktor penting, kualitas pelayanan yang lebih dekat untuk kepuasan konsumen akan memberikan harapan lebih dan sebaliknya. Dengan adanya kualitas pelayanan yang telah diberikan, maka secara tidak langsung kepuasan konsumen akan terwujud. ${ }^{1}$

Konsumen memiliki peluang yang luas untuk mendapatkan produk dengan sederet pilihan sesuai dengan keinginan dan kebutuhannya. Karena itu konsentrasi pemasaran tidak lagi sekedar bagaimana produk itu sampai ke konsumen tetapi lebih fokus kepada

${ }^{1}$ Lina Sari Situmeang, "Pengaruh Kualitas Pelayanan, Harga dan Lokasi Terhadap Kepuasan Konsumen Pada Rumah Makan Istana Hot Plate Medan". Skripsi tidak diterbitkan (Sumatera Utara: Jurusan Ekonomi Islam Fakiltas Ekonomi dan Bisnis Islam UIN Sumatera Utara, 2017), 1.

e-ISSN: 2686-6633 
apakah produk itu telah memenuhi permintaan kepuasan konsumen. Untuk itu diperlukan strategi inovasi penjualan terus berusaha agar dapat menarik calon konsumen menjadi konsumen yang tetap. Masalah pelayanan sebenarnya bukanlah hal yang sulit atau rumit, tetapi apabila hal ini kurang diperhatikan maka dapat menimbulkan hal-hal yang rawan karena sifatnya yang sangat sensitif. Sistem pelayanan perlu didukung oleh kualitas pelayanan, fasilitas yang memadai dan etika atau tata krama.

Minat pembelian konsumen merupakan masalah yang sangat kompleks, namun harus tetap menjadi perhatian pemasar. Minat konsumen untuk membeli dapat muncul sebagai akibat adanya rangsangan (stimulus) yang ditawarkan oleh pelaku usaha. Masing-masing stimulus tersebut dirancang untuk menghasilkan tindakan pembelian konsumen.

Minat beli merupakan pemusatan perhatian terhadap sesuatu yang disertai dengan perasaan senang terhadap barang tersebut, kemudian minat individu tersebut menimbulkan keinginan sehingga timbul perasaan yang meyakinkan bahwa barang tersebut mempunyai manfaat sehingga individu ingin memiliki barang tersebut dengan cara membayar atau menukar dengan uang. ${ }^{2}$

Khusus di Kota Palu Sulawesi Tengah, tepatnya di Kelurahan Kayumalue Kecamatan Palu Utara, bisnis kuliner nasi kuning ini merupakan bisnis yang memiliki

${ }^{2}$ Donni Juni Priansa, "Perilaku Konsumen Dalam Persaingan Bisnis Kontemporer" (Cet. I: Bandung : Alfabeta, cv, 2017), 164-165. prospek yang baik, ditambah lagi dengan adanya sekolah dan pabrikpabrik, sehingga peluang untuk mendapatkan pasar dan keuntungan dalam usaha kuliner semakin besar. Ada beberapa warung yang berjualan nasi kuning di kelurahan kayumalue, diantaranya adalah Kantin Sri, Warung Lina, Nasi Kuning Mama Upeng, Kantin TK Pembina, dan Nasi Kuning Puput. Dari beberapa warung nasi kuning tersebut menurut observasi peneliti, hanya Nasi Kuning Puput yang memiliki pelanggan paling banyak, padahal dari segi harga sama-sama menetapkan harga antara Rp. 5.000 -Rp. 12.000 Hal ini dikarenakan Nasi Kuning Puput memiliki tempat yang nyaman, rasa yang enak, area parkir yang luas, dan yang paling utama adalah pelayanan yang diberikan oleh pelaku usaha tersebut sangat baik.

Nasi Kuning Puput memiliki target pasar utama yaitu siswa, karyawan pabrik, dan masyarakat umum. Sedangkan keluhan dari konsumen yang menandakan terjadinya ketidakpuasan pelanggan menjadi tantangan bagi Nasi Kuning Puput untuk merubah dan mempertahankan harga yang terjangkau dan memperbaiki serta meningkatkan layanannya sehingga kepuasan konsumen dapat terjaga dan keuntungan penjualan dapat tetap terus meningkat. Kualitas pelayanan yang menjadi point utama dalam usaha kuliner ini, jika pelayanan diberikan secara maksimal tentu saja akan mempengaruhi loyalitas seorang konsumen.

Nasi Kuning Puput memiliki beberapa hal yang membedakan dengan warung nasi kuning yang lain terutama 
kualitas pelayanannya. Pertama dilihat dari segi keandalan (realibity) yang diberikan oleh pelaku usaha kepada konsumen dengan tidak membedabedakan konsumen dalam hal ini berlaku sistem antrian, dan sikap yang simpatik dapat dilihat dari pelayanannya yang murah senyum, ramah, berpakaian sopan dan jujur. Kedua daya tanggap (responsiviness), kesiapan pelaku usaha untuk memberikan pelayanan yang dibutuhkan pelanggan seperti melayani pembeli dengan cepat.

Ketiga dilihat dari segi jaminan (assurance), yaitu jaminan yang diberikan kepada pembeli seperti makanan yang disajikan tidak memiliki kesalahan (tidak terdapat rambut, kerikil dan lain-lain di dalam makanan). Keempat dilihat dari segi empati (emphaty) dimana pelaku usaha memberikan perhatian secara individu kepada konsumen. Misalnya hubungan komunikasi dan perhatian terhadap konsumen sehingga konsumen merasa kebutuhannya terpuaskan karena dirinya dilayani dengan baik. Kelima bukti fisik (tangible), ketersediaan tempat yang nyaman bagi pembeli yang ingin makan di tempat, serta area parkir yang luas dan aman.

Penelitian ini dilakukan untuk mengetahui apa yang sebenarnya diinginkan atau diharapkan oleh konsumen dan apa yang selama ini dipersepsikan oleh konsumen atas kualitas pelayanan yang diterimanya, yang menjadi pokok permasalahan dan pembahasan dalam kualitas pelayanan yang ada di warung Nasi Kuning Puput tersebut. Baik buruknya kualitas pelayanan akan tergantung pada kemampuan warung Nasi Kuning Puput tersebut untuk memenuhi harapan konsumennya.

\section{Tinjauan Pustaka}

\subsection{Kualitas Pelayanan}

Kata kualitas mengandung banyak definisi dan makna, tetapi dari beberapa definisi tersebut, beberapa yang memiliki persamaan walaupun hanya cara penyampaiannya saja, biasanya terdapat pada elemen sebagai berikut: 3

a. Kualitas meliputi usaha memenuhi atau melebihkan harapan pelanggan.

b. Kualitas mencakup produk, jasa, manusia, proses dan lingkungan.

c. Kualitas merupakan kondisi yang selalu berubah.

Konsep kualitas telah menjadi faktor yang sangat dominan terhadap keberhasilan dan suatu organisasi. Kualitas menjadi pedoman utama dalam pengembangan dan keberhasilan implementasi program-program manajerial dan kerekayasaan untuk mewujudkan tujuan-tujuan bisnis yang utama. Cara lain untuk melakukan diferensiasi adalah secara konsisten memberikan kualitas yang lebih baik dari pada pesaing. Hal ini dapat tercapai dengan memenuhi atau bahkan melampaui kualitas yang diharapkan oleh para pelanggan. Kualitas jasa atau layanan sendiri dipengaruhi oleh dua variabel, yaitu jasa layanan yang dirasakan (perceived service) dan jasa

${ }^{3}$ Philip Kotler, Manajemen Pemasaran Jilid 2, (Jakarta: PT Prenhallindo, 2002), h. 56.

e-ISSN: $2686-6633$ 
layanan yang diharapkan (expectedservice). ${ }^{4}$

Dalam perspektif TQM (Total Quality Manajemen), kualitas dipandang secara luas dimana tidak hanya aspek hasil saja yang ditekankan, melainkan juga meliputi proses lingkungan dan manusia sebagaimana dikemukakan oleh Gotesh dan Davis dalam Buddi Ibrahim bahwa kualitas merupakan suatu kondisi dinamis yang berhubungan dengan produk, jasa, manusia, proses dan lingkungan yang memenuhi dan melebihi harapan. ${ }^{5}$

Pelayanan/layanan juga merupakan salah satu aspek penting dalam mempertahankan bisnis dan memenangkan persaingan. Setiap pelaku usaha harus memberikan pelayanan yang semakin baik dari hari ke hari kepada konsumen. Menurut Kotler dalam siti nurjannah, pelayanan adalah kegiatan atau manfaat yang ditawarkan oleh suatu pihak kepada pihak lain yang pada dasarnya tidak menghasilkan kepemilikan. ${ }^{6}$

Kualitas layanan merupakan salah satu bagian dari pada pemasaran. Pengertian kualitas pelayanan menurut J.Supranto adalah sebuah kata yang bagi penyedia jasa merupakan sesuatu yang

${ }^{4}$ Tjiptono. F. Strategi Pemasaran, Edisi Ketiga, (Cet. III; Yogyakarta: CV. Andi Offset, 2008), 146.

${ }^{5}$ Buddy Ibrahim,TQM (total quality management). (Cet. II; Jakarta: Djambatan, 2000), 104.

6Siti Nurjannah, "Pengaruh Layanan Biro Administrasi Akademik Terhadap Loyalitas Mahasiswa Dengan Moderating Variabel Kepuasan Di Industri Pendidikan"Studi Kasus Institut Teknologi dan Bisnis Kalbe”, 2013: 208. harus dikerjakan dengan baik.7 Kualitas layanan diberikan kepada konsumen harus berfungsi untuk lebih memberikan kepuasan yang maksimal, oleh karena itu dalam rangka memberikan pelayanan harus dilakukan sesuai dengan fungsi pelayanan.

Konsep kualitas pelayanan merupakan cara untuk mengukur aktivitas pelayanan suatu organisasi melalui kinerja petugasnya terhadap konsumen sebagai pengguna jasa. Di dalam hal ini yang perlu dipahami adalah bahwa pelayanan berupa suatu aktivitas yang dijalankan untuk memberi manfaat bagi konsumen sebagaimana yang ditawarkan oleh suatu organisasi atau perseorangan. Menurut Fandy Tjiptono dimensi kualitas pelayanan terdiri dari: ${ }^{8}$

a. Keandalan (Reliability)

Dimensi keandalan yaitu kemampuan pelaku usaha untuk memberikan pelayanan sesuai yang dijanjikan secara akurat dan terpercaya. Kinerja harus sesuai dengan harapan pelanggan yang berarti ketepatan waktu, pelayanan yang sama untuk semua pelanggan tanpa kesalahan, sikap yang simpatik, dan dengan akurasi yang tinggi.

b. Daya tanggap (Responsiviness)

Dimensi daya tanggap kemauan atau kesiapan para pegawai untuk memberikan pelayanan yang dibutuhkan pelanggan. Suatu kebijaksanaan untuk memberikan

${ }^{7} \mathrm{~J}$ Supranto, Pengukuran Tingkat Kepuasan Pelanggan, (Cet. III; Jakarta: Rineka Cipta, 2006), 226.

${ }^{8}$ Fandy Tjiptono, Strategi Pemasaran Edisi 3. (Cet. III; Yogyakarta: ANDI, 2011), 232. 
layanan yang cepat kepada pelanggan, tidak membiarkan konsumen menunggu tanpa adanya suatu alasan yang jelas yang menyebabkan persepsi yang negatif dalam kualitas pelayanan. Pada peristiwa pelayanan gagal, kemampuan untuk segera mengatasi hal tersebut secara profesional dapat memberikan persepsi yang positif terhadap kualitas pelayanan. Jadi, para staf dapat membantu para pelanggan dan memberikan pelayanan yang tanggap dalam bekerja tanpa pelanggan berfikir negatif terhadap kualitas yang diberikan. ${ }^{9}$

c. Jaminan (Assurance)

Dimensi assurance (jaminan) berkenaan dengan pengetahuan atau wawasan, kesopanan, santun, kepercayaan diri dari pemberi layanan, serta respek terhadap konsumen. Apabila pemberi layanan bersikap respek, sopan santun dan kelemahlembutan maka akan meningkatkan persepsi positif dan nilai bagi konsumen terhadap lembaga penyedia jasa. Assurance ini akan meningkatkan kepercayaan, rasa aman, bebas dari resiko atau bahaya, sehingga membuat konsumen merasakan kepuasan dan akan loyal terhadap lembaga penyedia layanan. Baik buruknya layanan yang diberikan akan menentukan keberhasilan lembaga atau pelaku usaha pemberi jasa layanan.

d. Empati (Emphaty)

Dimensi Empati berkenaan dengan kemampuan pegawai untuk

${ }^{9}$ Donny Syahbana, "Pengaruh Lima Dimensi Kualitas Pelayanan Terhadap Kepuasan Anggota Koperasi Susu Warga Mulya Purwobinangun Pakem Sleman". Skripsi Tidak Diterbitkan peduli dan memberi perhatian secara individu kepada konsumen. Kemampuan ini yang ditujukan melalui hubungan, komunikasi, memahami, dan perhatian terhadap kebutuhan serta keluhan konsumen. Perwujudan dari sikap empati ini akan membuat konsumen merasa kebutuhannya terpuaskan karena dirinya dilayani dengan baik.

e. Bukti Fisik (Tangible)

Dimensi bukti fisik berupa fasilitas fisik seperti gedung, ruangan yang nyaman dan sarana dan prasarana lainnya. Penampilan dan kemampuan sarana dan prasarana fisik harus dapat diandalkan. Keadaan lingkungan sekitarnya adalah bukti nyata dari pelayanan yang diberikan oleh pemberi jasa. Misalnya: bank memiliki gedung bagus, peralatan komputer yang canggih, seragam karyawan atau karyawati yang menarik. ${ }^{10}$

Konsep Islam mengajarkan bahwa dalam memberikan layanan dari usaha yang dijalankan baik itu berupa barang atau jasa jangan memberikan yang buruk atau yang tidak berkualitas, melainkan yang berkualitas kepada orang lain. Hal ini didasarkan antara lain pada QS. Ali Imran (3) : 159 :

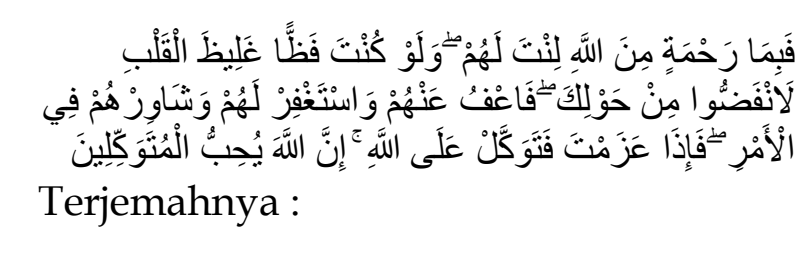

10Donny Syahbana, "Pengaruh Lima Dimensi Kualitas Pelayanan Terhadap Kepuasan Anggota Koperasi Susu Warga Mulya Purwobinangun Pakem Sleman". Skripsi Tidak Diterbitkan (Yogyakarta: Jurusan Pendidikan Ekonomi Fakultas Ekonomi Universitas Negeri Yogyakarta, 2016), 31.

e-ISSN: $2686-6633$ 
"Maka disebabkan rahmat dari Allah lah kamu berlaku lemah lembut terhadap mereka. Sekiranya kamu bersikap keras lagi berhati kasar, tentulah mereka menjauhkan diri dari sekelilingmu. Karena itu maafkanlah mereka, mohonkanlah ampun bagi mereka, dan bermusyawarahlah dengan mereka dalam urusan itu. Kemudian apabila kamu telah membulatkan tekad, maka bertawakallah kepada Allah, sesungguhnya Allah menyukai orang-orang yang bertawakal kepadaNya."11

Tafsirannya :

Sebagai wujud kasih sayang Allah kepada kamu dan mereka, kamu bersikap lemah lembut dan tidak berkata kasar karena kesalahan mereka. Dan seandainya kamu bersikap kasar dan keras, mereka pasti akan bercerai berai meninggalkanmu. Oleh sebab itu, lupakanlah kesalahan mereka. Mintakanlah ampunan untuk mereka. Dan ajaklah mereka bermusyawarah untuk mengetahui pendapat mereka dalam berbagai persoalan yang tidak disebut dalam wahyu. Apabila kamu telah bertekad untuk mengambil suatu langkah setelah terebih dahulu melakukan musyawarah, laksanakanlah langkah itu dengan bertawakkal kepada Allah, karena Allah benar-benar mencintai orang-orang yang menyerahkan urusan kepada-Nya. ${ }^{12}$

${ }^{11}$ Departemen Agama RI, Al Qur'an Dan Terjemahannya, (Bandung : PT. Sygma Examedia Arkanleema, 2015).

12 M. Quraish Shihab, Tafsir Al Misbah: Pesan, Kesan dan Keserasian Al-Qur'an (Cet. II; Vol. 2: Jakarta: Lentera Hati, 2002), h. 211.
Islam menghapus semua perbedaan kelas antar umat manusia dan menganggap amal sebagai kewajiban yang harus dilaksanakan oleh setiap orang sesuai dengan kapasitas dan kemampuan dirinya. Islam tidak mengakui dan mengingkari sebuah keimanan yang tidak membuahkan perilaku yang baik. Islam juga mengajarkan kepada umat manusia atau pekerja agar dalam memberikan pelayanan harus sesuai dengan Prinsip Ekonomi Islam. Memberikan pelayanan terbaik kepada umat manusia adalah pekerjaan yang sangat mulia dan meupakan pintu kebaikan bagi siapa saja yang meu melakukannya. Sebagian kecil dari Al-Qur'an dan Hadist yang mendorong umat manusia untuk memberikan pelayanan terbaik kepada sesama.

Dalam pandangan Islam, yang dijadikan tolak ukur untuk menilai kualitas pelayanan adalah standarisasi syariah. Islam mensyari'atkan kepada manusia agar selalu terikat dengan hukum syara' dalam menjalankan aktivitas ataupun memecahkan setiap masalah. Islam mengajarkan bila ingin memberikan hasil usaha baik berupa barang maupun jasa sebagaimana yang dijelaskan di bawah ini: ${ }^{13}$

a. Prinsip kesatuan atau tauhid (keesaan) ini merupakan wacana teologis yang mendasari aktifitas manusia, termasuk aktifitas bisnis

13 Marlena Eka, "Pengaruh Kualitas Pelayanan Terhadap Minat Beli Konsumen Menggunakan Jasa Transportasi Kereta Api Dalam Perspektif Ekonomi Islam". Skripsi Tidak Diterbitkan (Lampung : Fakultas Ekonomi Dan Bisnis Islam Universitas Islam Negeri Raden Intan Lampung, 2018), h. 16.

e-ISSN: 2686-6633 
yang dilakukan oleh manusia tidak terlepas dari pengawasan tuhan.

b. Prinsip keadilan dan keseimbangan ialah ajaran Islam berorientasi pada terciptanya karakter manusia yang memiliki sikap dan prilaku yang adil dalam konteks hubungan antara manusia dengan diri sendiri, dengan orang lain (masyarakat) dan dengan lingkungan.

c. Prinsip tanggung jawab, setiap pelaku dalam bisnis mempunyai tanggung jawab moral kepada tuhan atas perilaku bisnis yang mereka jalani.

d. Tidak menipu ( Al-kazib) yaitu merupakan sikap yang sangat mulia dalam menjalankan bisnisnya adalah tidak menipu di Stasiun Tanjung Karang Bandar Lampung dalam hal pembelian tiket, waktu pemberangakatan serta waktu sampai tempat yang dituju.

e. Melayani dengan rendah hati (khidmah) yaitu sikap ramah tamah, sopan santun, murah senyum, suka mengalah namun tetep penuh dengan tanggung jawab.

Sebagaimana yang dijelaskan dalam firman Allah Q.S Al-Nissa (4) : 29 yang berbunyi :

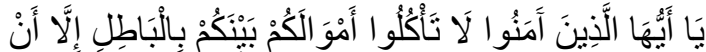

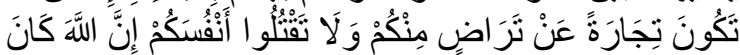

Terjemahannya :

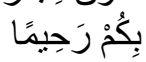

"Hai orang-orang yang beriman, janganlah kamu saling memakan harta sesamamu dengan jalan yang batil, kecuali dengan jalan perniagaan yang Berlaku dengan suka sama-suka di antara kamu. dan janganlah kamu membunuh dirimu;Sesungguhnya Allah adalah Maha Penyayang kepadamu"14

Tafsirannya :

Melalui ayat ini Allah mengingatkan, wahai orang-orang yang beriman, janganlah kamu memakan, yakni memperoleh harta yang merupakan sarana kehidupan kamu, di antara kamu dengan jalan yang batil, yakni tidak sesuai dengan tuntunan syariat, tetapi hendaklah kamu peroleh harta itu dengan jalan perniagaan yang berdasarkan kerelaan di antara kamu, kerelaan yang tidak melanggar ketentuan agama. Karena harta benda mempunyai kedudukan di bawah nyawa, bahkan terkadang nyawa dipertaruhkan untuk memperoleh atau mempertahankannya, maka pesan ayat ini selanjutnya adalah dan janganlah kamu membunuh diri kamu sendiri, atau membunuh orang lain secara tidak hak karena orang lain adalah sama dengan kamu, dan bila kamu membunuhnya kamu pun terancam dibunuh, sesungguhnya Allah terhadap kamu Maha Penyayang. 15

Penggunaan kata makan untuk melarang perolehan harta secara batil, dikarenakan kebutuhan pokok manusia adalah makan. Kalau makan yang

14Departemen Agama RI, Al Qur'an Dan Terjemahannya, (Bandung : PT. Sygma Examedia Arkanleema, 2015).

${ }^{15}$ M. Quraish Shihab, Tafsir Al Misbah: Pesan, Kesan dan Keserasian Al-Qur'an (Cet. II; Vol. 2: Jakarta: Lentera Hati, 2002), h. 411. 
merupakan kebutuhan pokok itu terlarang memperolehnya dengan batil, maka tentu lebih terlarang lagi, bila perolehan dengan batil menyangkut kebutuhan sekunder apalagi tersier. ${ }^{16}$

Dari pembahasan di atas, maka kualitas pelayanan merupakan suatu keharusan yang harus dimiliki oleh pelaku usaha baik yang memproduksi barang maupun jasa. Selain itu, kualitas pelayanan merupakan perbandingan antara kenyataan dan harapan konsumen, jika kenyataan ternyata yang diterima lebih dari yang diinginkan maka pelayanan yang diberikan dapat dikatakan baik dan dapat meningkatkan minat beli konsumen, dan sebaliknya jika kenyataan ternyata kurang dari apa yang diharapkan maka pelayanan dikatakan tidak baik dan menyebabkan minat beli konsumen menurun.

\subsection{Definisi Minat Beli}

Minat pembelian konsumen merupakan masalah yang sangat kompleks, namun harus tetap menjadi perhatian pemasar. Minat konsumen untuk membeli dapat muncul sebagai akibat adanya rangsangan (stimulus) yang ditawarkan oleh pelaku usaha. Masing-masing stimulus tersebut dirancang untuk menghasilkan tindakan pembelian konsumen.

Minat beli merupakan pemusatan perhatian terhadap sesuatu yang disertai dengan perasaan senang terhadap barang tersebut, kemuadian minat individu tersebut menimbulkan keinginan sehingga timbul perasaan yang meyakinkan bahwa barang tersebut mempunyai manfaat sehingga

\footnotetext{
${ }^{16}$ Ibid, 412
}

individu ingin memiliki barang tersebut dengan cara membayar atau menukar dengan uang.

a. Tahapan Minat Beli Konsumen

Tahapan minat beli konsumen dapat dipahami melalui model AIDA yang diuraikan oleh Kotler dan Keller dalam doni sebagai berikut: 17

1) Perhatian (attention)

Tahap ini merupakan tahap awal dalam menilai suatu produk atau jasa sesuai dengan kebutuhan calon pelanggan, selain itu calon pelanggan juga mempelajari produk atau jasa yang ditawarkan.

2) Tertarik (interest)

Dalam tahap ini calon pelanggan mulai tertarik untuk membeli produk atau jasa yang ditawarkan, setelah mendapatkan informasi yang lebih terperinci mengenai produk atau jasa yang ditawarkan.

3) Hasrat (desire)

Calon pelanggan mulai memikirkan serta berdiskusi mengenai produk atau jasa yang ditawarkan, karena hasrat dan keinginan untuk membeli mulai timbul. Dalam tahapan ini calon pelanggan sudah mulai berminat terhadap produk atau jasa yang ditawarkan. Tahap ini ditandai dengan munculnya minat yang kuat dari calon pelanggan untuk membeli dan mencoba produk atau jasa yang ditawarkan.

4) Tindakan (action)

Pada tahap ini calon pelanggan telah mempunyai kemantapan yang tinggi untuk membeli atau

\footnotetext{
${ }^{17}$ Donni Juni Priansa, Perilaku Konsumen Dalam Persaingan Bisnis Kontemporer (Cet. I: Bandung : Alfabeta, cv, 2017), h. 164-165.
}

e-ISSN: $2686-6633$ 
menggunakan produk atau jasa yang ditawarkan.

b. Dasar Hukum Minat Beli Konsumen

Sebelum melakukan pembelian, seorang penjual harus bisa membangkitkan minat beli konsumen. Salah satu caranya ialah dengan memperindah tampilan produk dan membuat promosi semenarik mungkin agar calon konsumen bisa melihat dan mau mencari informasi mmengenai produk yang ditawarkan penjual dan memang dalam melakukan suatu usaha untuk menarik minat beli konsumen itu tidak gampang karena mereka yang memiliki keputusan pembelian. Jadi sebagai penjual harus kreatif agar bisa mendapatkan pembeli dan menjadikannya pelanggan. Jika usaha yang dilakukan sudah maksimal, pasti akan ada hasil yang memuaskan ${ }^{18}$

\section{Metode Penelitian}

Pendekatan yang digunakan dalam penelitian ini adalah pendekatan kuantitaif, karena penelitian ini terfokus untuk mengetahui pengaruh variabel pengetahuan, kemudahan, dan resiko terhadap minta bertransaksi dengan Fintech.

Penelitian ini dilakukan di warung Nasi Kuning Puput, yang bertempat di Jalan Trans Sulawesi, Kelurahan Kayumalue, Kecamatan Palu Utara, Kota Palu, Provinsi Sulawesi Tengah. Peneliti memberikan questioner kepada 40 respondent konsumen nasi

\footnotetext{
${ }^{18}$ Mustafa Edwin Nasution, Pusat Pengkajian dan Pengembangan Ekonomi Islam, (Jakarta: Graha Ilmuop.cit,2011), h. 130.
}

kuning Puput. Quesioner menggunakan lima skala likert. ${ }^{19}, 20$

Teknik analisis data yang digunakan dalam penelitian ini adalah analisis kuantitaif, yaitu proses analisis terhadap data-data yang berbentuk angka dengan cara perhitungan secara statistik untuk mengukur pengaruh ketiga variabel tersebut terhadap minat menggunakan Fintech. an pembelian. ${ }^{21}$ Analisa data dilakukan melalui tahap uni validitas, reabilitas, uji regresi berganda, dan uji asumsi klasik. Untuk oembuktian hipotesis penulis menggunakan uji f dan uji t. ${ }^{22}$

\section{Hasil dan Pembahasan}

\subsection{Deskripsi Sample}

Deskripsi responden digunakan untuk menggambarkan keadaan atau

\section{${ }^{19}$ Nurdin, N., Pettalongi, S. S., \& Ahsan,} M. N. (2019). Implementation of Teaching Quality Assessment System Using Android. 2019 5th International Conference on Science and Technology (ICST),

${ }^{20}$ Nurdin, N., Pettalongi, S. S., \& Mangasing, M. (2019). Understanding Digital Skill Use from The Technology Continuance Theory (TCT). 2019 6th International Conference on Information Technology, Computer and Electrical Engineering (ICITACEE),

21 Nurdin, N., Musyawarah, I., Nurfitriani, N., \& Jalil, A. (2020). Pengaruh Pelayanan Mobile Banking Terhadap Kepuasan Nasabah (Studi Pada Mahasiswa Perbankan Syariah IAIN Palu) Jurnal Ilmu Perbankan dan Keuangan Syariah, 2(2), 87-104.

${ }^{22}$ Marzuki, M., \& Nurdin, N. (2020). The Influence of Halal Product Expectation, Social Environment, and Fiqih Knowledge on Intention to Use Shariah Financial Technology Products. International Journal of Innovation, Creativity and Change, 13(1), 171-193. 
kondisi responden sehingga dapat memberikan informasi tambahan serta memahami hasil-hasil penelitian. Penyajian data deskripsi penelitian bertujuan agar dapat dilihat dari data penelitian tersebut serta hubungan antara variabel yang digunakan dalam penelitian dengan jumlah responden.

a). Deskripsi responden berdasarkan jenis kelamin

Jenis kelamin merupakan perbedaan bentuk, sifat, dan fungsi biologi laki-laki dan perempuan yang menentukan perbedaan peran mereka dalam upaya menyelenggarakan upaya meneruskan garis keturunan. Adapun karakteristik responden berdasarkan jenis kelamin dapat dilihat pada tabel berikut ini :

Tabel 1. Jenis Kelamin Responden

\begin{tabular}{|c|c|c|c|}
\hline No & $\begin{array}{c}\text { Jenis } \\
\text { Kelamin }\end{array}$ & $\begin{array}{c}\text { Jumlah } \\
\text { (Orang) }\end{array}$ & $\begin{array}{c}\text { Persentase } \\
(\%)\end{array}$ \\
\hline 1 & Laki-Laki & 23 & 57,5 \\
\hline 2 & Perempuan & 17 & 42,5 \\
\hline \multicolumn{2}{|c|}{ Total } & $\mathbf{4 0}$ & $\mathbf{1 0 0}$ \\
\hline
\end{tabular}

Berdasarkan tabel 1 diatas, dapat dijelaskan bahwa sebagian besar yang menjadi responden adalah lakilaki yang berjumlah 23 orang dengan persentase $(57,5 \%)$ sedangkan sisanya merupakan responden perempuan yang berjumlah 17 orang dengan persentase sebesar $(42,5 \%)$.

b). Deskripsi responden berdasarkan tingkat usia

Usia yaitu untuk melihat kemampuan fisik dan kesehatan mental spiritual untuk melakukan kegiatan produksi. Tingkat kemampuan kerja dari manusia sangat tergantung pada tingkat usia.
Usia yang lebih mudah atau tua cenderung menuju pada kondisi yang belum atau sudah tidak optimal untuk bekerja. Adapun karakteristik responden berdasarkan tingkat usia dapat dilihat pada tabel berikut ini.

Tabel 2. Usia Respondent

\begin{tabular}{|c|c|c|c|}
\hline No & Usia & $\begin{array}{l}\text { Jumlah } \\
\text { (Orang) }\end{array}$ & $\begin{array}{c}\text { Persentase } \\
(\%)\end{array}$ \\
\hline 1 & $12-20$ & 11 & 27,5 \\
\hline 2 & $21-30$ & 15 & 37,5 \\
\hline 3 & $31-40$ & 6 & 15 \\
\hline 4 & $41->$ & 8 & 20 \\
\hline \multicolumn{2}{|c|}{ TOTAL } & 40 & 100 \\
\hline
\end{tabular}

Berdasarkan tabel 5, dapat dijelaskan bahwa yang menjadi responden adalah mereka yang mempunyai tingkat kematangan pengalaman dan wawasan yang cukup dalam pengambilan keputusan dan tindakan. Dimana responden yang paling banyak ialah mereka yang dalam kategori usia produktif, yakni berusia 21-30 tahun berjumlah 15 orang dengan persentase sebesar $(27,5 \%)$, usia $12-20$ tahun berjumlah 11 orang dengan persentase sebesar $(37,5 \%)$, usia $31-40$ tahun berjumlah 6 orang dengan persentase sebesar (15\%), dan usia 41 tahun ke atas berjumlah 8 orang dengan persentase sebesar $(20 \%)$.

\subsection{Hasil Uji Instrumen}

a). Uji Validitas

Uji validitas yaitu mengkorelasikan masing-masing pernyataan dengan jumlah skor untuk masing-masing variabel. Syarat minimum untuk memenuhi syarat e-ISSN: 2686-6633 
adalah apabila $r=0,3$ jadi apabila korelasi antar butir dengan skor total kurang dari 0,3 maka instrumen tersebut tidak valid. ${ }^{23}$

Melihat butir pertanyaan atau pernyataan yang valid adalah dengan melihat tabel Item Total Statistics, kemudian lihat pada kolom Corrected Item-Total Corelation.

Tabel. 3

Hasil Uji Validitas Instrumen

\begin{tabular}{|c|c|c|c|c|}
\hline $\begin{array}{c}\text { Variab } \\
\text { el }\end{array}$ & $\begin{array}{c}\text { Item } \\
\text { Pernyat } \\
\text { aan }\end{array}$ & $\begin{array}{c}\text { Correcte } \\
\text { IItem } \\
\text { Total } \\
\text { Correlat } \\
\text { ion }\end{array}$ & $\begin{array}{c}\mathbf{R} \\
\text { Krit } \\
\text { is }\end{array}$ & $\begin{array}{c}\text { Keteran } \\
\text { gan }\end{array}$ \\
\hline & & & & \\
& 1 & 0,369 & 0,3 & Valid \\
& 2 & 0,543 & 0,3 & Valid \\
& 3 & 0,455 & 0,3 & Valid \\
& 4 & 0,352 & 0,3 & Valid \\
& 5 & 0,376 & 0,3 & \\
& 6 & 0,515 & 0,3 & Valid \\
& 7 & 0,384 & 0,3 & Valid \\
& 8 & 0,354 & 0,3 & Valid \\
Kualita & 9 & 0,433 & 0,3 & Valid \\
Pelayan & 10 & 0,525 & 0,3 & Valid \\
an (X) & 11 & 0,525 & 0,3 & Valid \\
& 12 & 0,396 & 0,3 & Valid \\
& 13 & 0,407 & 0,3 & Valid \\
& 14 & 0,443 & 0,3 & Valid \\
& 15 & 0,456 & 0,3 & Valid \\
& 16 & 0,447 & 0,3 & Valid \\
& 17 & 0,576 & 0,3 & Valid \\
& 18 & 0,510 & 0,3 & Valid \\
& 19 & 0,289 & 0,3 & Valid \\
& 20 & 0,420 & 0,3 & Valid \\
& 21 & 0,363 & 0,3 & Valid \\
& 22 & 0,396 & 0,3 & Valid \\
& 23 & 0,402 & 0,3 & Valid \\
& 24 & 0,529 & 0,3 & Valid \\
& 25 & 0,424 & 0,3 & Valid \\
\hline
\end{tabular}

${ }^{23}$ Sugiyono, Metode Penelitian Kuantitatif, Kualitatif dan $R$ an $D$, (Cet.XIII; Bandung: CV. Alfabeta, 2011), 20.

\begin{tabular}{|c|c|c|c|c|}
\hline & & & & Valid \\
\hline & 1 & 0,363 & 0,3 & Valid \\
& 2 & 0,628 & 0,3 & Valid \\
& 3 & 0,695 & 0,3 & Valid \\
Minat & 4 & 0,739 & 0,3 & Valid \\
Beli (Y) & 5 & 0,656 & 0,3 & Valid \\
& 6 & 0,764 & 0,3 & Valid \\
& 7 & 0,494 & 0,3 & Valid \\
& 8 & 0,472 & 0,3 & Valid \\
\hline
\end{tabular}

Sumber data: Output SPSS 21,0 November 2019

Dari tabel 8 menunjukkan bahwa nilai r ritung pada kolom Corrected Item Total Correlation untuk masingmasing item memiliki $\mathrm{r}_{\text {hitung }}$ lebih besar dan positif dari 0,3 yang artinya dari kedua variabel diatas dinyatakan semua item pernyataan dalam variabel $X$ adalah valid dan pernyataan dalam variabel Y dinyatakan valid.

b). Uji Realibilitas

\section{Realibilitas}

mengandung pengertian bahwa suatu instrumen dapat dipercaya untuk digunakan sebagai pengumpul data karena instrumen tersebut valid. Instrumen yang valid tidak akan bersifat tandesius mengarahkan responden untuk memilih jawaban-jawaban tertentu.

Instrumen yang sudah dipercaya, yang reliable, akan menghasilkan data yang dapat dipercaya pula. Apabila datanya memang sesuai dengan kenyataannya, maka berapa kalipun diambil tetap akan sama. Alat ukur itu reliabel bila alat itu dalam mengukur suatu gejala pada waktu yang berlainan senantiasa menunjukan hasil yang sama.

Jadi alat yang reliabel secara konsisten memberi hasil ukuran yang sama. Untuk menguji ketepatan atau kepercayaan tersebut yaitu dengan menguji ketepatan antara pertanyaan dengan skor jawaban responden yang e-ISSN: 2686-6633 
dihasilkan. Selanjutnya dilakukan uji statistik yaitu dengan Alpha Cronbach. Suatu variabel dianggap reliabel jika nilai alpha di atas 0,6.

Hasil pengujuan realibilitas instrment menggunakan alat bantu statistik SPSS versi 21.0 for Windows dapat diketahui sebagaimana tabel berikut.

Tabel 4. Hasil Uji Reliabilitas

\begin{tabular}{|c|c|c|c|}
\hline Variabel & $\begin{array}{c}\text { Reliability } \\
\text { Coeficiens }\end{array}$ & $\begin{array}{c}\text { Cronbach } \\
\text { Alpha }\end{array}$ & Keterangan \\
\hline $\begin{array}{c}\text { Kualitas } \\
\text { Pelayanan } \\
\text { (X) }\end{array}$ & 25 Item & 0,873 & Reliabel \\
\hline $\begin{array}{c}\text { Minat Beli } \\
\text { (Y) }\end{array}$ & 8 Item & 0,85 & Reliabel \\
\hline
\end{tabular}

Tabel di atas dapat diketahui bahwa masing-masing variabel memiliki Cronbach's Alpha (a) lebih dari 0,60 (a > $0,60)$, yang artinya bahwa semua variabel yaitu $X$ dan $Y$ adalah reliabel. Dengan demikian pengolahan data dapat dilanjutkan ke jenjang selanjutnya. c). Deskripsi Variabel Penelitian

Setelah data terkumpul, selanjutnya ialah melakukan tabulasi data untuk melihat tanggapan responden mengenai variabel penelitian yaitu kualitas pelayanan (variabel independen), dan minat beli (variabel dependen). Kemudian dicari rata-rata dari setiap jawaban responden, untuk memudahkan penilaian rata-rata tersebut, maka dibuat interval. distribusi ditemukan tanggapan responden terhadap pernyataan dari masing-masing item pernyataan yang kedua yaitu minat beli, tanggapan responden mengenai hal tersebut sebanyak 20 orang menjawab sangat setuju dengan skor 110 dengan nilai presentase $50 \%$, 19 orang menjawab setuju dengan skor 76 dengan presentase $47,5 \%, 1$ orang menjawab kurang setuju dengan skor 3 dengan nilai persentase $2,5 \%$, serta tidak ada yang memilih tidak seyuju dan sangat tidak setuju. Maka total skor jawaban dari nilai $n 40$ responden adalah 179 dan nilai mean 4,47 .

Pada pernyataan yang kedua tanggapan responden mengenai hal tersebut sebanyak 22 orang menjawab sangat setuju dengan skor 110 dengan nilai presentase $55 \%, 18$ orang menjawab setuju dengan skor 72 dengan presentase $45 \%$, serta tidak ada yang memilih kurang setuju, tidak setuju dan sangat tidak setuju. Maka total skor jawaban dari nilai n 40 responden adalah 182 dan nilai mean 4,55.

Pada pernyataan yang ketiga tanggapan responden mengenai hal tersebut sebanyak 22 orang menjawab sangat setuju dengan skor 110 dengan nilai presentase $55 \%, 18$ orang menjawab setuju dengan skor 72 dengan presentase $45 \%$, serta tidak ada yang memilih kurang setuju, tidak setuju dan sangat tidak setuju. Maka total skor jawaban dari nilai n 40 responden adalah 182 dan nilai mean 4,55.

Pada pernyataan yang keempat menunjukan tanggapan responden mengenai hal tersebut sebanyak 23 orang menjawab sangat setuju dengan skor 115 dengan nilai presentase 57,5\%, 17 orang menjawab setuju dengan skor 68 dengan nilai presentase $42,5 \%$, serta tidak ada yang memilih kurang setuju, tidak setuju dan sangat tidak setuju. 
Maka total skor jawaban dari nilai n 40 responden adalah 183 dan nilai mean 4,57 .

Pada pernyataan yang kelima tanggapan responden mengenai hal tersebut sebanyak 26 orang menjawab sangat setuju dengan skor 130 dengan nilai presentase $65 \%, 14$ orang menjawab setuju dengan skor 56 dengan presentase $35 \%$, serta tidak ada yang memilih kurang setuju, tidak setuju dan sangat tidak setuju. Maka total skor jawaban dari nilai n 40 responden adalah 186 dan nilai mean 4,65.

Pada pernyataan yang keenam tanggapan responden mengenai hal tersebut sebanyak 22 orang menjawab sangat setuju dengan skor 110 dengan nilai presentase $55 \%$, 18 orang menjawab setuju dengan skor 72 dengan presentase $45 \%$, serta tidak ada yang memilih kurang setuju, tidak setuju dan sangat tidak setuju. Maka total skor jawaban dari nilai n 40 responden adalah 182 dan nilai mean 4,55.

Pada pernyataan yang ketujuh tanggapan responden mengenai hal tersebut sebanyak 23 orang menjawab sangat setuju dengan skor 115 dengan nilai presentase 57,5\%, 17 orang menjawab setuju dengan skor 68 dengan presentase $43,33 \%$, serta tidak ada yang memilih kurang setuju, tidak setuju dan sangat tidak setuju. Maka total skor jawaban dari nilai n 40 responden adalah 183 dan nilai mean 4,57.

Pada pernyataan yang kedelapan tanggapan responden mengenai hal tersebut sebanyak 22 orang menjawab sangat setuju dengan skor 110 dengan nilai presentase 55\%, 16 orang menjawab setuju dengan skor 64 dengan presentase $40 \%, 2$ orang menjawab kurang setuju dengan skor 6 dengan nilai persentase $5 \%$ serta tidak ada yang memilih tidak setuju dan sangat tidak setuju. Maka total skor jawaban dari nilai n 40 responden adalah 180 dan nilai mean 4,5.

\subsection{Hasil Analisis Data}

Sebelum metode regresi digunakan dalam pengujian hipotesis, terlebih dahulu model tersebut akan diuji apakah memenuhi asumsi klasik atau tidak. Uji asumsi klasik adalah persyaratan statistik yang harus dipenuhi pada analisis regresi linear sederhana. Asumsi klasik dimaksudkan untuk mengetahui apakah koefisien regresi yang didapatkan telah benar dan dapat diterima serta menghindari kemungkinan adanya pelanggaran asumsi klasik yang merupakan asumsi dasar dalam metode analisis regresi.

Tabel 5

Hasil Uji Asumsi Klasik Multikolinieritas

\begin{tabular}{|c|c|c|c|}
\hline \multirow{2}{*}{ Model } & \multicolumn{2}{|c|}{ Collinearity Statistics } & \multirow{2}{*}{ Keterangan } \\
\cline { 2 - 3 } & Tolerance & VIF & \\
\hline 1 & & & Non \\
$\begin{array}{c}\text { (Constant) } \\
\text { Kualitas } \\
\text { Pelayanan }\end{array}$ & 1,000 & 1,000 & multikolinieritas \\
\hline
\end{tabular}

Pada tabel 5 menunjukkan bahwa nilai tolerance pada variabel kualitas pelayanan bernilai 1,000 dan VIF bernilai 1,000. Nilai tolerance dari variabel ini lebih dari 0,10 dan nilai VIF adalah kurang dari 10. Sehingga dapat disimpulkan tidak terjadi multikolinieritas pada variabel bebas. b). Analisi Regresi Linear Sederhana

Berdasarkan hasil olah data menggunakan SPSS 21.0 for Windows 
diperoleh hasil analisis regresi sederhana sebagai berikut :

Tabel 6

Analisis Regresi Linear Sederhana

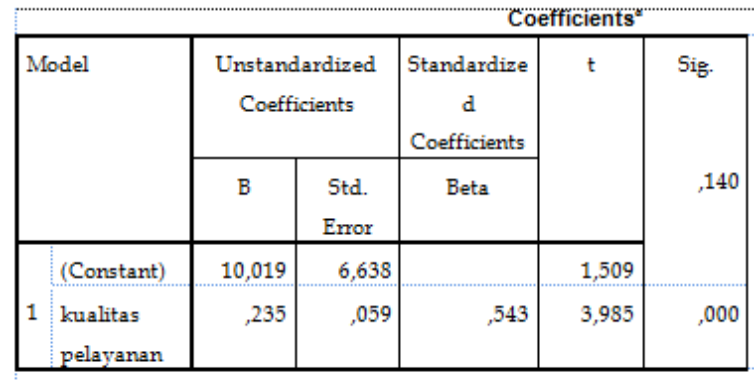

a. Dependent Variable: minat beli

Tabel 6 ini bertujuan untuk mengetahui besarnya Pengaruh Kualitas Pelayanan terhadap Minat Beli pada konsumen Nasi Kuning Puput.

Kualitas Pelayanan $(\mathrm{X})$ diperoleh nilai $T_{\text {hitung }} 3,985>T_{\text {tabel }} 2,001$ dan memiliki nilai signifikan (sig) 0.000 pada tabel coefficients dengan nilai a (tingkat signifikan) 0,05. Artinya 0,000 $<0,05$, dengan nilai ini memberikan makna bahwa variabel Kualitas Pelayanan (X) memberikan pengaruh secara signifikan terhadap minat beli (Y). Adapun besaran pengaruhnya dapat dilihat pada kolom Beta. Besaran pengaruh variabel (X) terhadap variabel $(\mathrm{Y})$ yaitu 0,543 atau $54,3 \%$.

Berdasarkan hasil perhitungan pada tabel 14, maka dapat dirumuskan persamaan regresi linear sederhana sebagai berikut:

\section{$0,543 X$}

$$
\mathrm{Y}=10,019+
$$

Dari persamaan regresi linear sederhana tersebut dapat dijelaskan sebagai berikut:

a. Nilai konstanta sebesar 10,019, menyatakan apabila variabel bebas dalam penelitian ini diabaikan atau sama dengan nol, maka minat beli (Y) akan bernilai tetap atau sebesar 10,019.

b. Nilai koefisien variabel Kualitas Pelayanan (X) bernilai positif yaitu sebesar 0,543 yang berarti setiap penambahan satu satuan variabel kualitas pelayanan maka akan meningkatkan minat beli sebesar 0,543 .

5. Pembuktian Hasil Hipotesis

Penelitian ini terdiri dari dua variable yaitu variabel Kualitas pelayanan (X) dan Minat Beli (Y). Dalam pengujian hipotesis penelitian ini menggunakan Uji T. Uji T digunakan untuk menguji apakah variabel independen benar-benar memberikan kontribusi terhadap variabel dependen. Berikut di bawah ini tabel hasil uji $\mathrm{T}$ pada tabel coeficients:

Tabel. 7

Hasil Uji Tabel Coeficiens

\begin{tabular}{|c|c|c|c|c|c|c|c|c|}
\hline \multicolumn{9}{|c|}{ Coefficients ${ }^{\mathrm{a}}$} \\
\hline \multirow{2}{*}{\multicolumn{2}{|c|}{ Model }} & \multicolumn{2}{|c|}{$\begin{array}{l}\text { Unstandardize } \\
\text { d Coefficients }\end{array}$} & \multirow{2}{*}{$\begin{array}{c}\begin{array}{c}\text { Standar } \\
\text { dized } \\
\text { Coefficie } \\
\text { nts }\end{array} \\
\text { Beta }\end{array}$} & \multirow[t]{2}{*}{ t } & \multirow[t]{2}{*}{ Sig. } & \multicolumn{2}{|c|}{$\begin{array}{l}\text { Collinearity } \\
\text { Statistics }\end{array}$} \\
\hline & & B & $\begin{array}{l}\text { Std. } \\
\text { Error }\end{array}$ & & & & Tolerance & VIF \\
\hline \multirow[b]{2}{*}{1} & (Constant) & 10,019 & 6,638 & & 1,509 & 234 & \multirow[b]{2}{*}{1,000} & \multirow[b]{2}{*}{1,000} \\
\hline & \begin{tabular}{|l|} 
kualitas \\
pelayanan
\end{tabular} & 235 & ,059 &, 543 & 3,985 &, 000 & & \\
\hline
\end{tabular}

Berdasarkan hasil perhitungan statistik uji $\mathrm{T}$ dari variabel independen yang dimasukkan dalam model regresi sederhana terlihat bahwa:

Hasil perhitungan statistik pada tabel di atas, maka dapat diketahui bahwa variabel kualitas pelayanan memiliki nilai $t_{\text {hitung }} 3,985>$ nilai $t_{\text {tabel }}$ 2,001, serta tingkat signifikansinya lebih kecil dari nilai alpha (a) yaitu 0,05. Artinya $0,000<0,05$. Dengan demikian nilai ini menunjukkan bahwa variabel Kualitas Pelayanan (X) memberikan 
pengaruh yang signifikan terhadap variabel Minat Beli (Y). Berdasarkan uji T tersebut, hipotesis dalam penelitian ini menyatakan bahwa "Diduga Kualitas Pelayanan berpengaruh terhadap Minat Beli Konsumen pada Nasi Kuning Puput." diterima.

\subsection{Pembahasan}

Hasil pengujian dengan menggunakan analisis regresi sederhana dengan bantuan SPSS 21.0 for Windows, Pengaruh Kualitas Pelayanan Terhadap Minat Beli Konsumen Nasi Kuning Puput di Kayumalue (Studi pada konsumen Nasi Kuning Puput di Kelurahan Kayumalue Kecamatan Palu Utara).

1. Pengaruh Kualitas Pelayanan Terhadap Minat Beli

Berdasarkan hasil uji statistik diperoleh nilai $t_{\text {hitung }} 3,985>t_{\text {tabel }} 2,001$ dan memilki nilai signifikan (sig) 0,000 pada tabel coefficients dengan nilai a (tingkat siginfikan) 0,05. Artinya 0,000 < 0,05 . Dengan nilai ini memberikan makna bahwa variabel Kualitas Pelayanan (X) memberikan pengaruh secara siginfikan terhadap Minat Beli (Y). Adapun besaran pengaruhnya dapat dilihat pada kolom Beta. Besaran pengaruh variabel $X$ terhadap variabel $Y$ yaitu 0,543 atau jika dipersentasekan yaitu 54,3\%. Hasil ini dapat memberikan gambaran bahwa responden (konsumen) memandang bahwa kualitas pelayanan sudah mampu mempengaruhi secara signifikan minat beli konsumen.

Pelayanan/layanan juga merupakan salah satu aspek penting dalam mempertahankan bisnis dan memenangkan persaingan. Setiap pelaku usaha harus memberikan pelayanan yang semakin baik dari hari ke hari kepada konsumen. Menurut Kotler pelayanan adalah kegiatan atau manfaat yang ditawarkan oleh suatu pihak kepada pihak lain yang pada dasarnya tidak menghasilkan kepemilikan. ${ }^{24}$

Kualitas layanan merupakan salah satu bagian dari pada pemasaran. Pengertian kualitas pelayanan menurut J.Supranto adalah sebuah kata yang bagi penyedia jasa merupakan sesuatu yang harus dikerjakan dengan baik. ${ }^{25}$ Kualitas layanan diberikan kepada konsumen harus berfungsi untuk lebih memberikan kepuasan yang maksimal, oleh karena itu dalam rangka memberikan pelayanan harus dilakukan sesuai dengan fungsi pelayanan.

Pengaruh kualitas pelayanan terhadap kepuasan konsumen dapat dibuktikan berdasarkan hasil analisis regresi linear sederhana yang menunjukkan bahwa variabel kualitas pelayanan berpengaruh terhadap minat beli konsumen dan memiliki arah yang positif terhadap minat beli konsumen dengan nilai konstanta 10,019 dan hasil koefisien sebesar 0,543 yang berarti jika terjadi peningkatan $1 \%$ pada kualitas pelayanan maka minat beli akan meningkat sebesar 1\%, hal ini menunjukkan jika terjadi peningkatan

\footnotetext{
24Siti Nurjannah, "Pengaruh Layanan Biro Administrasi Akademik Terhadap Loyalitas Mahasiswa Dengan Moderating Variabel Kepuasan Di Industri Pendidikan" Studi Kasus Institut Teknologi dan Bisnis Kalbe". Maret (2013), 208.

25J Supranto, Pengukuran Tingkat Kepuasan Pelanggan, (Cet III: Jakarta:Rineka Cipta, 2006), 226.
}

e-ISSN: $2686-6633$ 
kualitas pelayanan maka minat beli konsumen pun akan meningkat.

Penelitian ini juga sejalan dengan yang dilakukan oleh Eka Marlena yang menunjukkan bahwa variabel kualitas pelayanan berpengaruh terhadap Minat Beli Konsumen Menggunakan Jasa Transportasi Kereta Api. ${ }^{26}$ Hal ini dapat dilihat dari hasil $t_{\text {hitung }} 4,709>t_{\text {tabel }} 1,993$, walaupun dalam penelitian ini membahas mengenai penggunaan Jasa Trasportasi Kereta Api, akan tetapi dapat dikaitkan dengan minat beli komsumen, yang mana hal tersebut adalah sama-sama minat beli konsumen pada suatu barang atau jasa dan pelayanan yang diberikan kepada konsumen. Maka dari itu penulis memutuskan untuk menggunakan hasil penelitian ini sebagai tinjauan pustaka.

2. Pengaruh Kualitas Pelayanan

Terhadap Minat Beli Menurut Perspektif Ekonomi Islam

Konsep Islam mengajarkan bahwa dalam memberikan layanan dari usaha yang dijalankan baik itu berupa barang atau jasa jangan memberikan yang buruk atau yang tidak berkualitas, melainkan yang berkualitas kepada orang lain. Hal ini didasarkan antara lain pada QS. Ali Imran (3) : 159 :

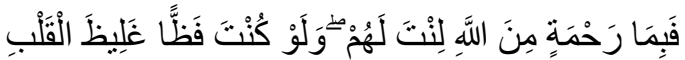

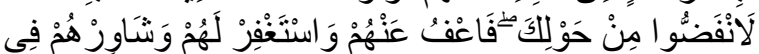

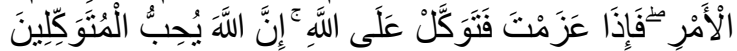
Terjemahnya :

\footnotetext{
${ }^{26}$ Dwi Endriani ” Pengaruh Brand Image dan Kualitas Layanan Terhadap Keputusan Pembelian Jasa Dalam Perspektif Ekonomi Islam(studi kasus pada pengguna jasa J\&T Express di Bandar Lampung)" skirpsi,( Bandar Lampung, Universitas islam negeri Raden Intan Lampung, 2018)
}

"Maka disebabkan rahmat dari Allah
lah kamu berlaku lemah lembut
terhadap mereka. Sekiranya kamu
bersikap keras lagi berhati kasar,
tentulah mereka menjauhkan diri
dari sekelilingmu. Karena itu
maafkanlah mereka, mohonkanlah
ampun bagi mereka, dan
bermusyawarahlah dengan mereka
dalam urusan itu. Kemudian apabila
kamu telah membulatkan tekad, maka
bertawakallah kepada Allah,
sesungguhnya Allah menyukai
orang-orang yang bertawakal
kepadaNya." 27 a

Tafsirannya :

Sebagai wujud kasih sayang Allah kepada kamu dan mereka, kamu bersikap lemah lembut dan tidak berkata kasar karena kesalahan mereka. Dan seandainya kamu bersikap kasar dan keras, mereka pasti akan bercerai berai meninggalkanmu. Oleh sebab itu, lupakanlah kesalahan mereka. Mintakanlah ampunan untuk mereka. Dan ajaklah mereka bermusyawarah untuk mengetahui pendapat mereka dalam berbagai persoalan yang tidak disebut dalam wahyu. Apabila kamu telah bertekad untuk mengambil suatu langkah setelah terebih dahulu melakukan musyawarah, laksanakanlah langkah itu dengan bertawakkal kepada Allah, karena Allah benar-benar mencintai orang-orang yang menyerahkan urusan kepada-Nya. ${ }^{28}$

${ }^{27}$ Departemen Agama RI, Al Qur'an Dan Terjemahannya, (Bandung : PT. Sygma Examedia Arkanleema, 2015).

${ }^{28}$ M. Quraish Shihab, Tafsir Al Misbah: Pesan, Kesan dan Keserasian Al-Qur'an (Vol. 2: Jakarta: Lentera Hati, 2002), h. 211.

e-ISSN: 2686-6633 
Dalam pandangan Islam, yang dijadikan tolak ukur untuk menilai kualitas pelayanan adalah standarisasi syariah. Islam mensyari'atkan kepada manusia agar selalu terikat dengan hukum syara' dalam menjalankan aktivitas ataupun memecahkan setiap masalah. Islam mengajarkan bila ingin memberikan hasil usaha baik berupa barang maupun jasa sebagaimana yang dijelaskan di bawah ini:

f. Prinsip kesatuan atau tauhid (keesaan) ini merupakan wacana teologis yang mendasari aktifitas manusia, termasuk aktifitas bisnis yang dilakukan oleh manusia tidak terlepas dari pengawasan tuhan.

g. Prinsip keadilan dan keseimbangan ialah ajaran Islam berorientasi pada terciptanya karakter manusia yang memiliki sikap dan prilaku yang adil dalam konteks hubungan antara manusia dengan diri sendiri, dengan orang lain (masyarakat) dan dengan lingkungan.

h. Prinsip tanggung jawab, setiap pelaku dalam bisnis mempunyai tanggung jawab moral kepada tuhan atas perilaku bisnis yang mereka jalani.

i. Tidak menipu ( Al-kazib) yaitu merupakan sikap yang sangat mulia dalam menjalankan bisnisnya adalah tidak menipu di Stasiun Tanjung Karang Bandar Lampung dalam hal pembelian tiket, waktu pemberangakatan serta waktu sampai tempat yang dituju.

j. Melayani dengan rendah hati (khidmah) yaitu sikap ramah tamah, sopan santun, murah senyum, suka mengalah namun tetep penuh dengan tanggung jawab.

Sebagaimana yang dijelaskan dalam firman Allah Al-Qur'an surah An-Nissa (4) ayat 29 yang berbunyai :

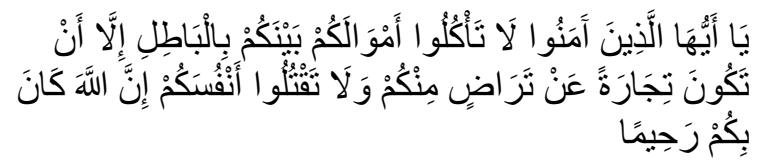

Terjemahannya :

"Hai orang-orang yang beriman, janganlah kamu saling memakan harta sesamamu dengan jalan yang batil, kecuali dengan jalan perniagaan yang Berlaku dengan suka sama-suka di antara kamu. dan janganlah kamu membunuh dirimu;Sesungguhnya Allah adalah Maha Penyayang kepadamu"29

Tafsirannya :

Melalui ayat ini Allah mengingatkan, wahai orang-orang yang beriman, janganlah kamu memakan, yakni memperoleh harta yang merupakan sarana kehidupan kamu, di antara kamu dengan jalan yang batil, yakni tidak sesuai dengan tuntunan syariat, tetapi hendaklah kamu peroleh harta itu dengan jalan perniagaan yang berdasarkan kerelaan di antara kamu, kerelaan yang tidak melanggar ketentuan agama. Karena harta benda mempunyai kedudukan di bawah nyawa, bahkan terkadang nyawa dipertaruhkan untuk memperoleh atau mempertahankannya, maka pesan ayat ini selanjutnya adalah dan janganlah

${ }^{29}$ Departemen Agama RI, Al Qur'an Dan Terjemahannya, (Bandung : PT. Sygma Examedia Arkanleema, 2015).

e-ISSN: $2686-6633$ 
kamu membunuh diri kamu sendiri, atau membunuh orang lain secara tidak hak karena orang lain adalah sama dengan kamu, dan bila kamu membunuhnya kamu pun terancam dibunuh, sesungguhnya Allah terhadap kamu Maha Penyayang. ${ }^{30}$

Penggunaan kata makan untuk melarang perolehan harta secara batil, dikarenakan kebutuhan pokok manusia adalah makan. Kalau makan yang merupakan kebutuhan pokok itu terlarang memperolehnya dengan batil, maka tentu lebih terlarang lagi, bila perolehan dengan batil menyangkut kebutuhan sekunder apalagi tersier. ${ }^{31}$

\section{Kesimpulan}

Kesimpulan yang sesuai dengan perumusan masalah yakni hasil Penelitian ini menyimpulkan bahwa kualitas pelayanan berpengaruh besar terhadap minat beli konsumen pada Nasi Kuning Puput di Kayumalue. Dimana besaran pengaruhnya dapat dilihat pada tabel Cofficients pada kolom Standardized Coefficient yaitu sebesar 0,543 atau $54,3 \%$, sedangkan sisanya dijelaskan oleh variable independen lain yang tidak termasuk dalam penelitian ini. Dalam Perspektif Ekonomi Islam Nasi Kuning Puput telah terwujud hubungan antara manusia karena pelaku usaha Nasi Kuning Puput tidak membedakan-bedakan antara konsumen yang satu dengan konsumen yang

\footnotetext{
${ }^{30}$ M. Quraish Shihab, Tafsir Al Misbah: Pesan, Kesan dan Keserasian Al-Qur'an (Vol. 2: Jakarta: Lentera Hati, 2002), h. 411.

${ }^{31}$ Ibid, 412
}

lainnya, semua dilayani dengan ramah, cepat dan tanggap.

\section{Daftar Pustaka}

Angga, Aptaguna. Pengaruh Kualitas Layanan dan Harga Terhadap Minat Beli Jasa GO-JEK. Widyakala Vol.3 Maret, 2016.

Ariani, Desi dan Bambang Munas Dwiyanto. Analisis Pengaruh Supply Chain Management Terhadap Kinerja Perusahaan. Studi pada industri kecil dan menengah makanan olahan khas Padang, Sumatra Barat. Diponegoro Journal, Vol.10 , No.2,2013. 7 Februari, 2019.

Azwar, Saifudin. Metode Penelitian. Yogyakarta: Pustaka Pelajar, 2011.

Cahyo, Prasetyo. Analisis Pengaruh Relationship Marketing Dalam Mencapai Kepuasan Pelanggan Pada Bisnis Jasa Transportasi Po. Raya. Skripsi di terbitkan. Surakarta: Jurusan Studi Manajemen Universitas Muhammadiyah Surakarta, 2012.

Departemen Agama RI, Al Qur'an Dan Terjemahannya, Bandung : PT. Sygma Examedia Arkanleema, 2015.

Eka, Marlena. Pengaruh Kualitas Pelayanan Terhadap Minat Beli Konsumen Menggunakan Jasa Transportasi Kereta Api Dalam Perspektif Ekonomi Islam. Skripsi Tidak di Terbitkan. Lampung : Fakultas Ekonomi Dan Bisnis Islam Universitas Islam Negeri Raden Intan Lampung, 2018. 
F, Tjiptono. Strategi Pemasaran. Edisis Ketiga. Yogyakarta: CV. Andi Offset, 2008.

Ferdinand, Augusty. 2006. Metode Penelitian Manajemen. Semarang: Badan Penerbit Universitas Diponegoro.

Ibrahim, Buddy. TQM (total quality management). Jakarta: Djambatan, 2000.

Katsir, Ibnu. Tafsir Ibnu Katsir. http://www.ibnukatsironline.co $\mathrm{m} / 2015 / 10 /$ tafsir-surat-najmayat-31-34.html. 01 Oktober 2019.

Kotler, Philip. Manajemen Pemasaran Jilid 2. Jakarta: PT Prenhallindo, 2002.

Muhammad. Metodologi Penelitian Ekonomi Islam Pendekatan Kuantitatif. Jakarta: Rajawali Pers, 2008.

Nabila, Mahfuza. Pengaruh Kualitas Pelayanan Terhadap Minat Membeli Konsumen pada Mini Market Indomaret di Kota Medan. Skripsi Tidak Diterbitkan. Medan : Fakultas Psikologi Universitas Sumatera Utara Medan, 2018.

Nasution, Mustafa Edwin. Pusat Pengkajian dan Pengembangan Ekonomi Islam. Jakarta: Graha Ilmuop.cit, 2011.

Nurdin, N., Pettalongi, S. S., \& Ahsan, M. N. (2019). Implementation of Teaching Quality Assessment System Using Android. 2019 5th International Conference on Science and Technology (ICST),

Nurdin, N., Pettalongi, S. S., \& Mangasing, M. (2019). Understanding Digital Skill Use from The Technology Continuance Theory (TCT). 2019 6th International Conference on Information Technology, Computer and Electrical Engineering (ICITACEE),

Nurdin, N., Musyawarah, I., Nurfitriani, N., \& Jalil, A. (2020). Pengaruh Pelayanan Mobile Banking Terhadap Kepuasan Nasabah (Studi Pada Mahasiswa Perbankan Syariah IAIN Palu) Jurnal Ilmu Perbankan dan Keuangan Syariah, 2(2), 87-104.

Marzuki, M., \& Nurdin, N. (2020). The Influence of Halal Product Expectation, Social Environment, and Fiqih Knowledge on Intention to Use Shariah Financial Technology Products. International Journal of Innovation, Creativity and Change, 13(1), 171193.

Nurjannah, Siti. Pengaruh Layanan Biro Administrasi Akademik Terhadap Loyalitas Mahasiswa Dengan Moderating Variabel Kepuasan Di Industri Pendidikan. Studi Kasus Institut Teknologi dan Bisnis Kalbe. Maret, 2013.

Nurul, Penitasari. Pengaruh Harga dan Kualitas Produk Terhadap Minat Beli Abon Lele Bang Zay. Skripsi Tidak diterbitkan. Malang : Program Studi Menejemen Fakultas Ekonomi dan Bisnis Universitas Muhammadiyah Malang, 2017.

Philip, Kotler dan Keller, Kevin Lane. 2008. Manajemen Pemasaran. Jakarta: Edisi 12, PT.Indeks.

Priansa, J. Donni. Perilaku Konsumen Dalam Persaingan Bisnis Kontemporer. Cet. I; Bandung: Alfabeta, 2017. 
Rita, Pemilik Nasi Kuning Puput, wawancara, 2019

Rizki, Beni. Analisis Pengaruh Ikalan Flexi Terhadap Minat Beli Konsumen Studi pada Masyarakat Kec. Tampan Pekanbaru, Skripsi Program Studi Manajemen UIN SUSKA Riau, Pekanbaru, 2012.

Saepul H. Asep dan Bahruddin E., Metode Penelitian Kuantitatif Aplikasi Dalam Pendidikan. Cet I : Yogyakarta: Deepublish, 2014.

Sarjono, Haryadi dan Winda Julianti. SPSS vs LISREL Sebuah Pengantar, Aplikasi untuk Riset. Jakarta: Salemba Empat, 2011.

Shihab, M. Quraish. Tafsir Al Misbah: Pesan, Kesan dan Keserasian AlQur'an . Vol. 2: Jakarta: Lentera Hati, 2002.

Situmeang, Lina Sari. Pengaruh Kualitas Pelayanan, Harga dan Lokasi Terhadap Kepuasan Konsumen Pada Rumah Makan Istana Hot Plate Medan. Skripsi tidak diterbitkan. Sumatera Utara: Jurusan Ekonomi Islam Fakultas Ekonomi dan Bisnis Islam UIN Sumatera Utara, 2017.

Singarimbun, Masri. Metode Penelitian Survei. Jakarta: LP3S, 1995.

Sugiyono. Metode Penelitian Kuantitatif, Kualitatif dan $R$ an D. Cet. XXI: Bandung: CV. Alfabeta, 2011.

Sunyoto, Danang. Analisis Regresi dan Uji Hipotesis. Yogyakarta: CAPS, 2011.

Supranto, J. Pengukuran Tingkat Kepuasan Pelanggan. Cet. Ketiga; Jakarta: Rineka Cipta, 2006.

Riduan dan Adnun Rusyana Emas. Cara mudah belajar SPSSS 17.0 dan
Aplikasi Statistik Penelitian. Cet.III, Bandung ALFABETA, 2013.

Tjiptono, Fandy. Strategi Pemasaran Edisi 3. Yogyakarta: ANDI, 2011. 